\title{
Induced lactation in heifers: Effects of dexamethasone and age at induction on milk yield and composition
}

\author{
A. L. Macrina, ${ }^{1}$ A. C. W. Kauf, ${ }^{2}$ D. A. Pape-Zambito, ${ }^{3}$ and R. S. Kensinger ${ }^{4}$ \\ Department of Animal Science, The Pennsylvania State University, University Park 16802
}

\begin{abstract}
Milk production in heifers induced into lactation is lower than that of postpartum primiparous cows. A method to improve milk production in induced lactations may provide opportunities for increased profitability as well as increase our understanding of the mechanisms that regulate mammary gland development and colostrum composition. The present study was conducted to determine if dexamethasone administration at the onset of milking or age at lactation induction would affect milk production in heifers induced into lactation. Holstein heifers at $14[\mathrm{n}=20$; $354 \pm 38 \mathrm{~kg}$ of body weight (BW)] and 18 mo of age ( $\mathrm{n}=20 ; 456 \pm 30 \mathrm{~kg}$ of BW) were assigned randomly to dexamethasone (DEX) or control $(\mathrm{CON})$ treatment groups in a $2 \times 2$ factorial arrangement with age and dexamethasone treatment as the 2 factors. Heifers were induced into lactation with daily subcutaneous injections of estradiol- $17 \beta$ and progesterone (0.075 and 0.25 $\mathrm{mg} / \mathrm{kg}$ of BW per d, respectively) on experimental d 1 to 7 . They also received bovine somatotropin (bST) every $14 \mathrm{~d}$ beginning on experimental d 1. Milking began on experiment d 18 (lactation d 1). Dexamethasone (10 $\mathrm{mg}$ ) was administered on lactation d 1 and 2 following the morning milking; $\mathrm{CON}$ heifers did not receive dexamethasone. Milk yield from d 2 to 15 of lactation of heifers receiving DEX $(7.8 \mathrm{~kg} / \mathrm{d})$ was greater than that of CON heifers $(6.0 \mathrm{~kg} / \mathrm{d})$ but was similar thereafter through $305 \mathrm{~d}$ of lactation $(18.2 \mathrm{~kg} / \mathrm{d})$. Milk production to d 11 was similar for 14- and 18-mo-old heifers but was greater for $18-(18.9 \mathrm{~kg} / \mathrm{d})$ than for 14 -mo-old animals $(17.4 \mathrm{~kg} / \mathrm{d})$ through $305 \mathrm{~d}$ in milk. Milk fat percentage increased initially and was greater in DEX (4.51\%) compared with CON $(3.53 \%)$ heifers until 21 $\mathrm{d}$ in milk. Milk protein and lactose concentrations were
\end{abstract}

\footnotetext{
Received July 8, 2013.

Accepted November 13, 2013.

${ }^{1}$ Corresponding author: ALM106@psu.edu

${ }^{2}$ Current location: Woodbury, PA.

${ }^{3}$ Current affiliation: Department of Biological Sciences, University of the Sciences, Philadelphia, PA 19104.

${ }^{4}$ Current affiliation: Department of Animal Science, The Ohio State University, Columbus 43210.
}

not affected by DEX treatment. Age at induction did not affect milk fat, protein, or lactose percentages. Mean milk IgG concentration declined from $107.4 \mathrm{mg} /$ $\mathrm{mL}$ on $\mathrm{d} 1$ to $5.0 \mathrm{mg} / \mathrm{mL}$ on d 7 of lactation, tended to be greater for 18- compared with 14-mo-old heifers, and was not different due to DEX treatment. Administration of DEX to heifers induced into lactation increased initial milk production during the first $2 \mathrm{wk}$ of lactation but this effect did not persist through 305 DIM. Treatment with DEX appeared to stimulate mammary cell differentiation but did not change the rate of decline of milk IgG concentrations. Higher milk yield in 18-moold heifers may be due to greater mammary epithelium, higher body mass, or both.

Key words: induced lactation, dairy heifer, dexamethasone, age

\section{INTRODUCTION}

Lactation can be induced successfully in 15-mo-old dairy heifers; however, they produce less milk than postpartum animals (Smith and Schanbacher, 1974; Macrina et al., 2011b). This is not surprising considering they are much younger than postpartum heifers that calve at 24 to 25 mo of age. A benefit to inducing lactation at a young age is that milk could be harvested and sold before heifers are old enough to calve. Current lactation-induction methods are based on the 7-d estrogen-progesterone injection protocol developed by Smith and Schanbacher (1973); however, lower doses of estradiol have been used (Erb et al., 1976; Byatt et al., 1997; Magliaro et al., 2004). Administration of bST to heifers during induced lactation increases milk production by $14.7 \%$ compared with control animals that did not receive bST (Macrina et al., 2011b). However, even with bST supplementation, inducing lactation in 15 -mo-old heifers is not more profitable than conventional rearing methods, where heifers calve at 25 mo (Macrina et al., 2011b). The potential exists to increase the economic value of induced lactation by improving milk production. In a previous study, Macrina et al. (2011a) reported a $36 \%$ increase in milk production by 15 -mo-old heifers that received bST concurrent with the estrogen-progesterone treatment to induce lactation. 
Milk production in heifers induced into lactation increases slowly compared with that in postpartum animals (Smith and Schanbacher, 1973; Kensinger et al., 1979; Fowler et al., 1991), and peak yields are not attained until well after 50 DIM (Macrina et al., 2011a,b). Mammary gland development may continue for longer after milking begins in heifers induced into lactation compared with postpartum animals. It has been speculated that heifers treated with bST at the same time estrogen and progesterone are administered to induce lactation have a greater number of mammary epithelial cells (MEC) compared with heifers that do not receive bST during this time (Macrina et al., 2011a). In that study, heifers reached peak milk production at 149 DIM, which appears to be slightly sooner than the $175 \mathrm{~d}$ to peak yield when heifers were treated with bST after induced lactation was established (Macrina et al., 2011b). It is not known if early administration of bST affected the extent or rate of MEC differentiation. Keys et al. (1989) calculated that $78 \%$ of the milk production difference between Holstein and Hereford cows was due to differences in secretory capacity per cell. Almost all of the MEC from Holstein parenchymal tissue were highly or intermediately differentiated, whereas $40 \%$ of those from Herefords were poorly differentiated (Akers et al., 2006). A strategy to increase the proportion of highly differentiated cells has the potential to improve milk yields in heifers induced into lactation.

Administration of reserpine or recombinant placental lactogen has also been investigated as a means to stimulate mammary development and improve milk production in cattle induced into lactation. Reserpine caused an increase in plasma prolactin concentrations (Collier et al., 1975, 1977; Peel et al., 1978); however, the results for milk production were variable, with some studies reporting an increase (Collier et al., 1975, 1977) and others showing no effect (Peel et al., 1978; Davis et al., 1983). Total mammary DNA is higher in heifers induced into lactation and treated with recombinant placental lactogen (rbPL) compared with controls, recombinant prolactin did not have an effect, and both stimulated mammary differentiation (Byatt et al., 1994). In a subsequent study, the same group reported that $\mathrm{rbPL}$ administration resulted in a $20 \%$ increase in milk yield through 9 wk of lactation but this was not statistically significant due to high coefficients of variation (Byatt et al., 1997). Although both prolactin and rbPL show promise for increasing milk production in induced lactations, synthetic glucocorticoids such as dexamethasone are more readily available.

Plasma levels of glucocorticoids increase around the time of parturition, and glucocorticoids are required for differentiation of mammary epithelial cells (Heald, 1974; Casey and Plaut, 2007). The synthetic glucocor- ticoid dexamethasone (DEX) has been used in some induced-lactation protocols. Heifers that received DEX produced more milk initially, but by d 21 all inducedlactation treatments resulted in similar milk production (Fulkerson, 1978). The treatments that used DEX were $42 \mathrm{~d}$ in length with estrogen and progesterone administered every $3 \mathrm{~d}$. The only induced-lactation treatment that did not include DEX was one that involved the standard administration of estrogen and progesterone for $7 \mathrm{~d}$. Chakriyarat et al. (1978) reported that DEX administered at the onset of milking increased the number of animals that produced $>5 \mathrm{~kg} / \mathrm{d}$ but did not improve overall milk yield in cows $(\mathrm{n}=13)$ and heifers $(\mathrm{n}=6)$ induced into lactation using the 7 -d estradiolprogesterone protocol. Increased success rate in cows also was observed by Davis et al. (1983). Overall, very little research has been conducted to evaluate the effects of DEX administration on milk yields of heifers induced into lactation.

Furthermore, limited feed intake capacity at 15 mo may have contributed to the longer time for heifers induced into lactation to reach peak production (Macrina et al., 2011b). Currently, the optimal age at which to induce lactation is not known. It is possible that older heifers could produce more milk than their younger herdmates. Studies to examine the effects of age and DEX administration on milk production could provide useful information on optimizing milk production in heifers induced into lactation. Although induced lactation has not been approved by the US Food and Drug Administration, the need for increased food production over the next $50 \mathrm{yr}$ might make it a viable technology. In addition, data collected on heifers induced into lactation could shed light on the regulation of mammary gland development and colostrum composition. The objectives of the present experiment were to determine if DEX administration at the onset of milking or older age at induction of lactation would increase milk production and affect mammary secretion composition in heifers induced into lactation.

\section{MATERIALS AND METHODS}

Estrous cycles were synchronized using 2 injections of prostaglandin $\mathrm{F}_{2 \alpha} 14 \mathrm{~d}$ apart so that heifers would be in a similar phase of the cycle upon induction of lactation. Heifers were induced in 5 different groups (October, February, April, June, and September) with 8 animals/group beginning on $\mathrm{d} 4 \pm 1$ of the estrous cycle. Holstein heifers at $14(\mathrm{n}=20 ; 354 \pm 38 \mathrm{~kg}$ of $\mathrm{BW})$ and $18 \mathrm{mo}$ of age $(\mathrm{n}=20 ; 456 \pm 30 \mathrm{~kg}$ of $\mathrm{BW})$ were induced into lactation using daily subcutaneous injections of estradiol-17 $\beta(0.075 \mathrm{mg} / \mathrm{kg}$ of BW; E-8875, Sigma-Aldrich, St. Louis, MO) and progesterone (0.25 
$\mathrm{mg} / \mathrm{kg}$ of BW; P-0130, Sigma-Aldrich) for d 1 to 7 of the experiment. The hormone solution was prepared in absolute ethanol to achieve $15 \mathrm{mg} / \mathrm{mL}$ estradiol- $17 \beta$ and $50 \mathrm{mg} / \mathrm{mL}$ progesterone, and injection volumes ranged from 1.5 to $2.6 \mathrm{~mL}$. Bovine somatotropin (500 mg; Posilac, Elanco Animal Health, Greenfield, IN) was administered to all heifers beginning on experimental d 1 along with the estrogen-progesterone treatment. Heifers continued to receive bST every 2 wk until 2 wk before dry off.

During the induction phase of the study, animals were housed in a temperature-controlled barn in individual tiestalls to prevent injury due to estrous-like behavior associated with the estrogen-progesterone treatment. Lights were on for $16 \mathrm{~h}$ and off for $8 \mathrm{~h}$; however, the building had windows so animals were also subjected to sunlight of varying amounts depending on the time of year. Heifers were assigned randomly to DEX or control $(\mathbf{C O N})$ treatment groups in a $2 \times 2$ factorial arrangement with age and level of dexamethasone as the 2 factors. Milking began on d 18 of the experiment (d 1 of lactation). Dexamethasone (D-1756, SigmaAldrich) was prepared in absolute ethanol to achieve a concentration of $10 \mathrm{mg} / \mathrm{mL}$, and $1.0 \mathrm{~mL}(10 \mathrm{mg}$ ) was administered subcutaneously on d 1 and 2 of lactation following the morning milking; CON heifers did not receive DEX.

Heifers were milked once per day until production reached approximately $3 \mathrm{~kg}$. They were then milked twice daily for the remainder of lactation. Heifers returned to the Penn State University dairy herd at 15 $\mathrm{d}$ of lactation and were subject to the same management protocols as other cows in the herd. Milk yield was measured daily, and milk samples were collected on lactation d 1, 3, 5, 7, 14, 21, and monthly thereafter for the entire lactation. Milk samples were analyzed by DHIA on a 4400 Combi Foss analyzer (Foss, Hillerød, Denmark). Aliquots of the milk samples collected from $\mathrm{d} 1$ to 7 were frozen at $-20^{\circ} \mathrm{C}$ and subsequently analyzed for IgG content by ELISA (E10-118, Bethyl Laboratories, Montgomery, TX). Day 1, 3, 5, and 7 samples were serially diluted 1:2,000,000, 1: 1,000,000, 1:50,000, and 1:25,000, respectively, before analysis so that concentrations were in the range of the standard curve. Inter- and intraassay coefficients of variation were 8.4 and $4.9 \%$, respectively.

Heifers were weighed monthly to monitor growth. In addition, health, reproduction, and calving data were collected for each animal. Two heifers were removed from the study on lactation d 14 due to poor milk production. One was an 18-mo-old CON heifer that produced $1.5 \mathrm{~kg}$ of milk on $\mathrm{d} 14$. The other was a 14-mo-old CON heifer that produced $0.2 \mathrm{~kg}$ of milk on $\mathrm{d} 14$.
During the induction phase, animals were fed a TMR designed to meet the nutrient requirements of lategestation dairy cows (NRC, 1989). Two days before milking commenced (experiment d 16), heifers received a mixture containing equal parts of the dry cow TMR and a lactating cow TMR. Once milking began, animals received the lactating cow TMR ad libitum. They continued to receive the same lactating cow TMR in freestall housing after their return to the Penn State University dairy herd. Diet compositions (Table 1) are representative of those fed over the 2-yr course of this research. This experiment was approved by the Institutional Animal Care and Use Committee at the Pennsylvania State University.

Effects due to age and level of dexamethasone in the induced heifers were analyzed using Proc Mixed in SAS (version 9.1, SAS Institute Inc., Cary, NC). The model included age group, level of DEX treatment, induction group, day of lactation, and first-order interactions. Subject was heifer (age $\times$ DEX level $\times$ group), and lactation day was used as the repeated measure with an autoregressive type 1 covariance matrix. Correlations were analyzed using Proc Corr in SAS.

\section{RESULTS}

Milk production was greater $(7.8 \mathrm{~kg} / \mathrm{d})$ in inducedlactation heifers that received DEX than in control

Table 1. Diet composition and analyses for representative diets used

\begin{tabular}{lcc}
\hline & $\begin{array}{c}\text { Dry } \\
\text { cow TMR }\end{array}$ & $\begin{array}{c}\text { Lactating } \\
\text { cow TMR }\end{array}$ \\
\hline Ingredient, \% of DM & & \\
Alfalfa hay, chopped & - & 6.7 \\
Alfalfa hay silage & - & 13.6 \\
Grass hay, chopped & 25.1 & - \\
Corn silage & 44.5 & 27.2 \\
Straw & - & 3.5 \\
Ground corn & - & 14.4 \\
Canola meal & 8.3 & 5.8 \\
Cookie meal & 4.8 & 5.3 \\
Soybeans, cooked & - & 2.6 \\
Soybean meal, 48\% & 6.2 & 8.4 \\
Distillers grains & 1.2 & 3.4 \\
Wheat middlings & 1.8 & 3.4 \\
Soy hulls & 6.0 & 1.8 \\
Molasses & 0.6 & 0.21 \\
Tallow & - & 0.64 \\
Aragonite & 0.39 & 0.29 \\
Salt & 0.14 & 2.73 \\
Vitamin-mineral mix & 0.98 & \\
Composition & & 51.3 \\
DM, \% & 51.7 & 17.8 \\
CP, \% & 14.0 & 19.4 \\
ADF, \% & 27.1 & 33.3 \\
NDF, \% & 49.4 & 0.84 \\
Ca, \% & 0.50 & 0.47 \\
P,\% & 0.36 & 0.78 \\
NE, Mcal/kg of DM & 0.72 & \\
\hline
\end{tabular}


Table 2. Effect of age at induction and dexamethasone (DEX) administration on 305-d yield and composition of milk from heifers induced into lactation ${ }^{1}$

\begin{tabular}{|c|c|c|c|c|c|c|c|}
\hline Component & \multicolumn{2}{|c|}{ Age at induction } & \multicolumn{2}{|c|}{ Treatment } & $\mathrm{SE}$ & \multicolumn{2}{|c|}{$P<$} \\
\hline Milk yield, $\mathrm{kg} / \mathrm{d}$ & 17.4 & 18.9 & 18.2 & 18.2 & 0.23 & 0.01 & NS \\
\hline Days to peak milk yield & 162 & 159 & 164 & 157 & 15 & NS & NS \\
\hline Fat, $\%$ & 3.92 & 4.10 & 4.15 & 3.87 & 0.17 & NS & NS \\
\hline Protein, \% & 3.45 & 3.40 & 3.48 & 3.37 & 0.13 & NS & NS \\
\hline
\end{tabular}

${ }^{1}$ The age and DEX levels were arranged as a $2 \times 2$ factorial. We observed no significant interactions, and data are presented separately for age groups $(\mathrm{n}=19$ per age group) and DEX levels $(\mathrm{n}=20$ DEX, $\mathrm{n}=18$ control). Heifers in the DEX treatment group received 10 mg of dexamethasone on $\mathrm{d} 1$ and 2 of lactation.

heifers $(6.0 \mathrm{~kg} / \mathrm{d})$ from d 2 to 15 of lactation $(P<0.05$; Figure 1). Milk yields, however, were similar thereafter until 305 DIM (Table 2). Milk production to d 11 was similar for 14- and 18-mo-old heifers, but milk yield was greater for 18 -mo-old $(19.1 \mathrm{~kg} / \mathrm{d})$ than for 14 -moold animals $(17.6 \mathrm{~kg} / \mathrm{d})$ through 305 DIM $(P<0.01$; Figure 2). Time to peak production averaged $160 \mathrm{~d}$ and was similar for both age groups. However, heifers induced at 18 mo had higher peak yields $(26.1 \mathrm{~kg} / \mathrm{d})$ than those induced at $14 \mathrm{mo}(22.9 \mathrm{~kg} / \mathrm{d}$; Table 2$)$.

Milk fat percentage was greater $(P<0.01)$ over $\mathrm{d} 1$ to 21 of lactation in DEX $(4.51 \%)$ compared with control heifers $(3.53 \%)$. We observed a DEX $\times$ day interaction, with DEX heifers having a faster initial increase in fat percentage compared with controls (Table $3 ; P<0.01$ ). However, by d 14 of lactation, milk fat percentage was similar for DEX and control heifers (Table 3) and remained similar through 305 DIM (Table 2). Age at induction had no effect on milk fat percentage (Tables 2 and 3). Milk protein and lactose percentages were not different due to DEX treatment or age at induction

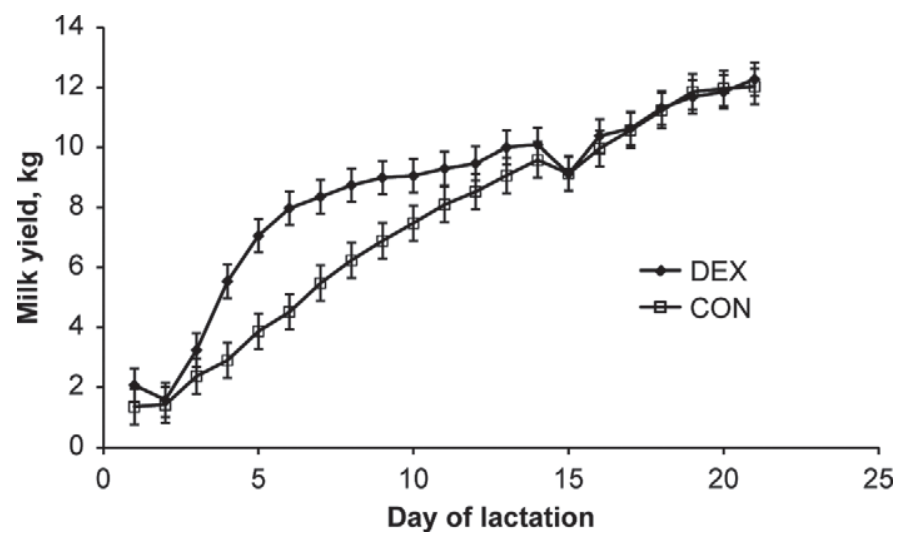

Figure 1. Comparison of initial milk yields of heifers induced into lactation and treated with $10 \mathrm{mg}$ of dexamethasone (DEX) on $\mathrm{d} 1$ and 2 of lactation with induced heifers not treated with dexamethasone $(\mathrm{CON})$. Significant treatment $\times$ time interaction, $\mathrm{SE}=0.56, P<0.01$.
(Tables 2 and 3). Protein content decreased over the first $21 \mathrm{~d}$ of lactation from $14.41 \%$ on $\mathrm{d} 1$ to $3.73 \%$ on d $21(P<0.01 ;$ Table 3$)$. Lactose percentage increased from 2.72 to $5.09 \%$ during the same period $(P<0.01$; Table 3). Somatic cell count decreased more rapidly in DEX-treated heifers compared with controls $(P<0.01$; Table 3); however, we observed no differences due to heifer age.

Mean milk IgG concentration, but not mass, tended to be greater for 18- versus 14-mo-old heifers $(P<0.08$; Table 3$)$ and declined from d 1 to $7(P<0.01)$. Treatment with DEX had no effect on IgG concentration or mass in colostrum or milk and did not affect the rate of decline over time. Concentration of IgG was correlated with milk yield $(\mathrm{r}=-0.60, P<0.01)$ and with $\operatorname{IgG}$ mass $(\mathrm{r}=0.23, P<0.01)$ over $\mathrm{d} 1$ to 21 of lactation.

Body weights 6 mo after lactation induction averaged $510 \pm 50 \mathrm{~kg}$ (20 mo of age) for the heifers induced at 14 mo and $580 \pm 34 \mathrm{~kg}$ (24 mo of age) for those induced at 18 mo. This reflects ADG of 0.82 and 0.67 for the 14- and 18-mo-old treatment groups during this 7-mo

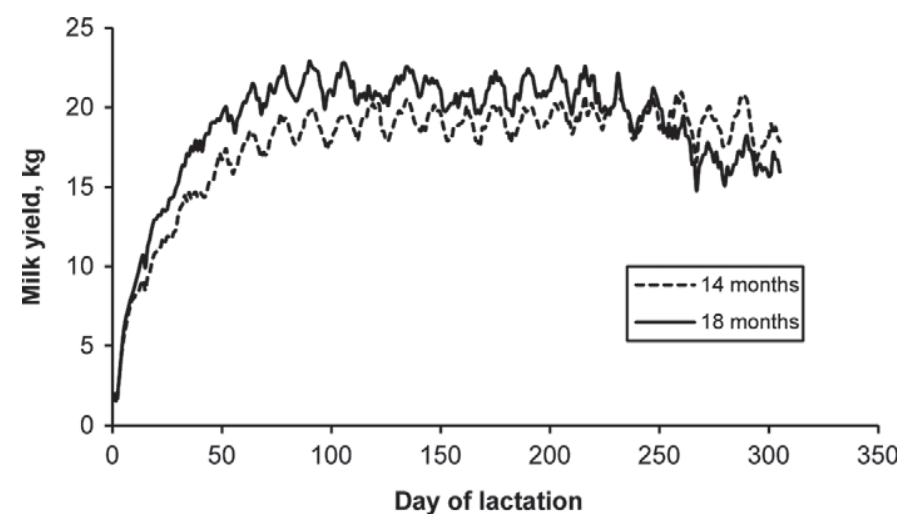

Figure 2. Milk yields through 305 DIM of heifers induced into lactation at 14 mo and 18 mo of age. Heifers induced at 18 mo produced more milk than those induced at $14 \mathrm{mo}(\mathrm{SE}=0.23, P<0.01)$. 
Table 3. Effect of age at induction and dexamethasone (DEX) administration on initial composition of milk from heifers induced into lactation ${ }^{1}$

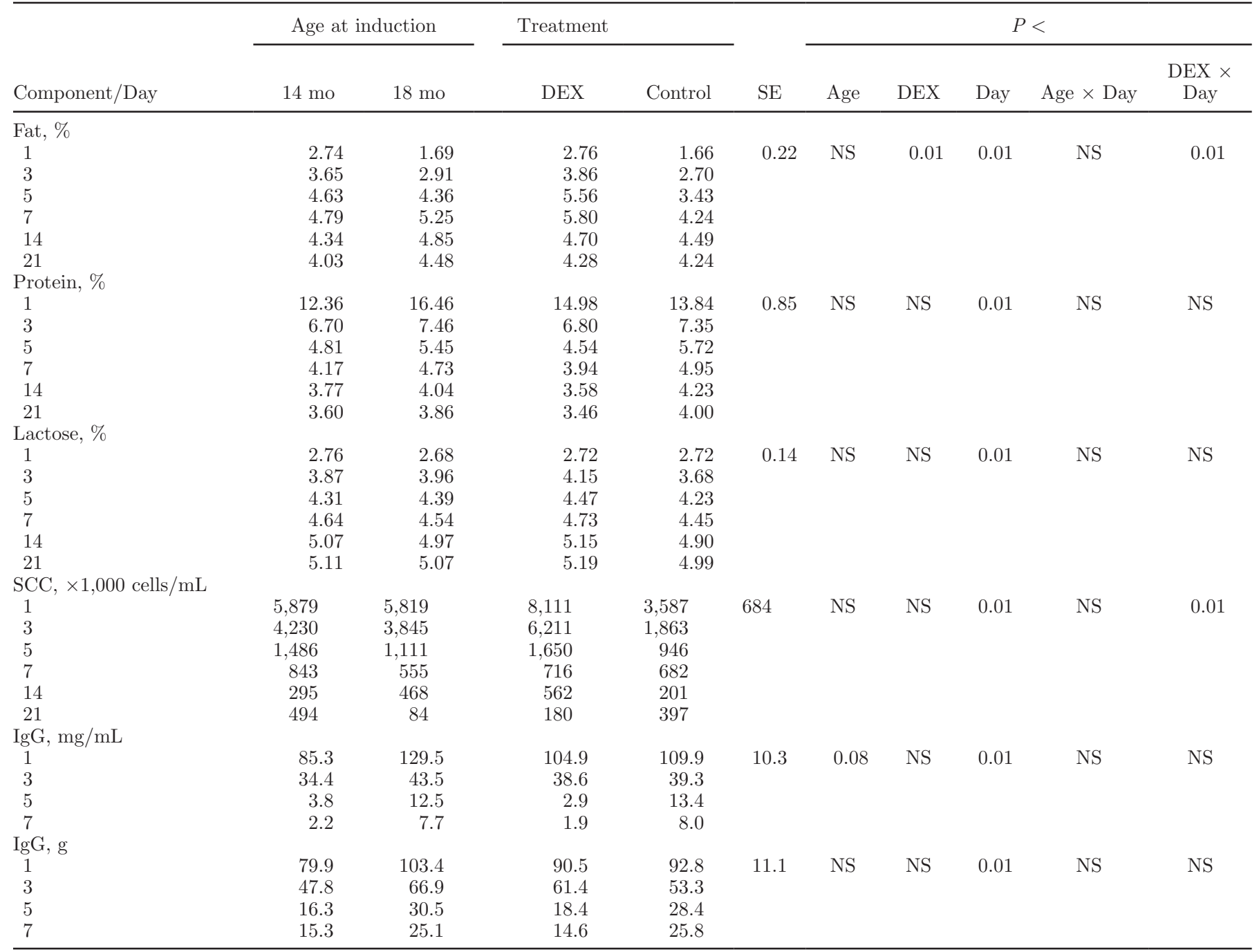

${ }^{1}$ Heifers in the DEX treatment group received $10 \mathrm{mg}$ of dexamethasone on $\mathrm{d} 1$ and 2 of lactation. Milk production was measured daily and a significant DEX $\times$ Day interaction was observed $(P<0.01)$.

period. At 24 mo of age, mean BW for heifers induced at 14 mo was $577 \pm 35 \mathrm{~kg}$, similar to that observed in heifers induced at 18 mo.

\section{DISCUSSION}

Heifers induced into lactation at 18 mo of age produced $8.6 \%$ more milk than heifers induced at 14 mo. This difference was apparent by $11 \mathrm{~d}$ of lactation and was sustained through 305 DIM. The older heifers had a greater capacity for feed intake and thus may have had greater substrate delivery to the mammary gland. Estimates of DMI were calculated using equations published by NRC (2001). Variables included were mean daily $4 \%$ FCM yield and BW at $22 \mathrm{wk}$ of lactation. Estimates of DMI were 15.6 and $17.6 \mathrm{~kg}$ for 14- and 18-mo-old heif- ers, respectively. Corresponding calculated net energy intake estimates were 12.1 and $13.7 \mathrm{Mcal} / \mathrm{d}$ for 14 - and 18-mo-old heifers, respectively. These estimates should be used with caution because it is not known if the equations for DMI are accurate for lactating animals of this age. The equation for predicting DMI was based on data collected from primiparous and multiparous cows (NRC, 2001). Milk energy estimates calculated according to Tyrrell and Reid (1965) using mean milk yield, fat percentage, and protein percentage were 12.9 and 14.4 Mcal for 14- and 18-mo-old heifers, respectively. The 1.6 Mcal difference in energy intake was similar to the $1.5 \mathrm{Mcal}$ difference in milk energy; thus, it is likely that the increased production observed in the older heifers primarily was due to higher feed intake. This is supported by the fact that $4 \%$ FCM, milk energy, milk 
fat, and milk protein at $22 \mathrm{wk}$ of lactation expressed on a metabolic body size basis $\left(\mathrm{BW}^{0.75}\right)$ were similar between the heifers induced into lactation at 14 and 18 mo of age (data not shown).

Heifers that calved at $<23$ mo of age had lower BW and first-lactation yields of milk and milk components compared with older heifers (Van Amburgh et al., 1998; Ettema and Santos, 2004). Clark and Touchberry (1962) showed that BW at calving had more influence on firstlactation milk production than did age at first calving. Prepubertal heifers induced into lactation produced 40 to $800 \mathrm{~mL}(0.04$ to $0.83 \mathrm{~kg}$ ) of milk on d 40 of lactation (Ball et al., 2000). This is substantially less than the approximately $16 \mathrm{~kg}$ produced by 15 -mo-old induced heifers at 40 DIM in the present and previous studies (Macrina et al., 2011a,b). The prepubertal heifers (Ball et al., 2000) would have far less feed intake capacity to support milk production, and this was observed to a lesser extent in the present study. Prepubertal heifers also have less mammary parenchymal tissue compared with heifers past puberty (Sinha and Tucker, 1969). Although prepubertal heifers induced into lactation and postpartum heifers are different from the 14- and 18-mo-old heifers induced in the present study, it is clear that BW can affect milk production.

Heifers that received DEX had a faster increase in milk production compared with $\mathrm{CON}$ heifers during the first $2 \mathrm{wk}$ of milking. Dexamethasone has been shown to stimulate differentiation of mammary epithelial cells (Heald, 1974; Casey and Plaut, 2007); therefore, it is plausible that the increased production was due to greater MEC differentiation during that time. However, CON heifers reached a similar level of production compared with DEX heifers by d 15 of lactation, suggesting that a similar level of differentiation was reached, albeit later in the CON heifers.

Milk composition was unaffected by age at induction. However, milk fat percentage increased more rapidly in the DEX-treated heifers after the onset of milking. This corresponds to the more rapid increase in milk production and would be expected if there was an increased rate of MEC differentiation or a greater proportion of highly differentiated MEC. We also expected a faster rate of decline in milk protein and a more rapid increase in milk lactose. We observed numerical differences between DEX and CON heifers in protein and lactose percentages from d 1 through 21 of lactation; however, they were not statistically significant.

The first secretions produced were colostrum-like and contained an elevated level of IgG compared with secretions collected at subsequent milkings. Concentrations of IgG on d 1 of milking averaged $107 \pm 82 \mathrm{mg} / \mathrm{mL}$. In a review, Butler (1983) reported mean concentrations of $46 \mathrm{mg} / \mathrm{mL}$ (range of 30 to $75 \mathrm{~g}$ ) for colostrum from postpartum cows, which are lower than concentrations observed in the present study. However, the d 1 concentrations for our heifers were within the range reported by Baumrucker et al. (2010) for the first milking of 214 postpartum cows, but the mean concentration in their study was only $37.5 \mathrm{mg} / \mathrm{mL}$. Total mass of $\mathrm{IgG}$ contained in the first milking secretions in the present study averaged $92 \mathrm{~g}$, which was markedly lower than the mean mass of $292 \mathrm{~g}$ reported by Baumrucker et al. (2010). Heifers in the present study had very low milk yields at the first milking (mean $=1,350 \mathrm{~mL}$, range of 23 to $4,722 \mathrm{~mL}$ ), which explains the low mass accumulation in spite of the high concentration. Milk on $\mathrm{d} 7$ from heifers in the present study contained an average of $4.2 \mathrm{mg} / \mathrm{mL} \mathrm{IgG} \mathrm{with} \mathrm{a} \mathrm{range} \mathrm{of} 0.6$ to 24.5 $\mathrm{mg} / \mathrm{mL}$. The concentrations at the lower end of this range are similar to the concentrations of 0.33 to 1.2 $\mathrm{mg} / \mathrm{mL}$ previously reported for milk (Butler, 1983). The higher level in milk from some of our heifers likely reflects the slow transition from colostrum to mature milk, which is observed in induced lactations (Magliaro et al., 2004; Macrina et al., 2011a,b). This is supported by the strong correlation between milk yield and IgG concentration. This correlation was evident even when statistical analyses were performed separately for individual days.

The 18-mo-old heifers tended to have higher concentrations of IgG in their secretions compared with 14-mo-old heifers. The older heifers had a larger body mass and may have had more total serum IgG available for transport into mammary secretions. However, treatment with DEX did not affect IgG content. This was unexpected because milk production increased more rapidly in the DEX-treated animals compared with controls. Glucocorticoids are required for MEC differentiation after which cellular secretory activity increases (Heald, 1974; Casey and Plaut, 2007). In a study of prepartum milking, IgG transport into mammary secretions decreased as cellular activity increased in both milked and unmilked udder quarters (Guy et al., 1994). Winger et al. (1995) reported sharp declines in milk IgG content $3 \mathrm{~d}$ after DEX administration to cows induced into lactation; cows that did not receive DEX showed a similar decline, but it occurred at a later time. Mean IgG concentrations of 15 to $22 \mathrm{mg} / \mathrm{mL}$ (Winger et al., 1995) were lower than those in the present study. This difference is likely related to the lower production at first milking for heifers in the present study. The mass of IgG ranges from 35 to $104 \mathrm{~g}$ (Winger et al., 1995) and is similar to the mean IgG mass for our heifers. The CON and DEX heifers in the current study in the present study may have had similar plasma glucocorticoid concentrations, and this could have resulted in similar rates of IgG decline in milk; alternatively, 
other factors are involved in control of IgG transport. Regulation of IgG transport into mammary secretions is not fully understood. Use of an induced-lactation model would facilitate studies designed to evaluate the effects of hormones on IgG transport independent of late pregnancy and parturition.

\section{CONCLUSIONS}

Heifers induced into lactation at $18 \mathrm{mo}$ of age produced more milk than those induced at 14 mo of age. This could be accounted for, in large part, by higher feed intake capacity of the older animals; however, a greater mammary epithelial mass in the older heifers may also explain the results. It is not known if the increased milk production from inducing lactation at an older age would make induced lactation profitable. Treatment of induced heifers with DEX caused an initial increase in milk yield that may be due to earlier differentiation of MEC; however, this increase was not sustained throughout lactation. Heifers induced at 18 mo of age tended to have higher concentrations of $\mathrm{IgG}$ in mammary secretions during the first week of lactation than heifers induced at 14 mo of age, but mass transfer of IgG was similar. Dexamethasone treatment did not affect concentration or mass of $\mathrm{IgG}$ in mammary secretions or the rate of decline after the onset of milking. Induced lactation can be used as a tool to study transport of immunoglobulins or other factors into colostrum without the confounding effects of pregnancy or parturition.

\section{ACKNOWLEDGMENTS}

This work was supported by Hatch funds and by USDA special grant no. 96-34281-3028 to R. S. Kensinger. The authors thank Dante Pighetti, Mark Amsler, Virginia Ishler, Nadine Houck, and other colleagues at the Penn State Dairy Research and Education Center (University Park) for their contributions.

\section{REFERENCES}

Akers, R. M., A. V. Capuco, and J. E. Keys. 2006. Mammary histology and alveolar cell differentiation during late gestation and early lactation in mammary tissue of beef and dairy heifers. Livest. Sci. 105:44-49.

Ball, S., K. Polson, J. Emeny, W. Eyestone, and R. M. Akers. 2000. Induced lactation in prepubertal Holstein heifers. J. Dairy Sci. $83: 2459-2463$

Baumrucker, C. R., A. M. Burkett, A. L. Magliaro-Macrina, and C. D. Dechow. 2010. Colostrogenesis: Mass transfer of $\operatorname{IgG}_{1}$ into colostrum. J. Dairy Sci. 93:3031-3038.

Butler, J. E. 1983. Bovine immunoglobulins: An augmented review. Vet. Immunol. Immunopathol. 4:43-152.

Byatt, J. C., P. J. Eppard, J. J. Veenhuizen, T. L. Curran, D. F. Curran, M. F. McGrath, and R. J. Collier. 1994. Stimulation of mam- mogenesis and lactogenesis by recombinant bovine placental lactogen in steroid-primed dairy heifers. J. Endocrinol. 140:33-43.

Byatt, J. C., R. H. Sorbet, P. J. Eppard, T. L. Curran, D. F. Curran, and R. J. Collier. 1997. The effect of recombinant bovine placental lactogen on induced lactation in dairy heifers. J. Dairy Sci. 80:496-503.

Casey, T. M., and K. Plaut. 2007. The role of glucocorticoids in secretory activation and milk secretion, a historical perspective. J. Mammary Gland Biol. Neoplasia 12:293-304.

Chakriyarat, S., H. H. Head, W. W. Thatcher, F. C. Neal, and C. J. Wilcox. 1978. Induction of lactation: Lactational, physiological, and hormonal responses in the bovine. J. Dairy Sci. 61:1715-1724.

Clark, R. D., and R. W. Touchberry. 1962. Effect of body weight and age at calving on milk production in Holstein cattle. J. Dairy Sci. 45:1500-1510.

Collier, R. J., D. E. Bauman, and R. L. Hays. 1975. Milk production and reproductive performance of cows hormonally induced into lactation. J. Dairy Sci. 58:1524-1527.

Collier, R. J., D. E. Bauman, and R. L. Hays. 1977. Effect of reserpine on milk production and serum prolactin of cows hormonally induced into lactation. J. Dairy Sci. 60:896-901.

Davis, S. R., R. A. Welch, M. G. Pearce, and A. J. Peterson. 1983. Induction of lactation in nonpregnant cows by estradiol-17 $\beta$ and progesterone from an intravaginal sponge. J. Dairy Sci. 66:450-457.

Erb, R. E., E. L. Monk, T. A. Mollett, P. V. Malven, and C. J. Callahan. 1976. Estrogen, progesterone, prolactin and other changes associated with bovine lactation induced with estradiol-173 and progesterone. J. Anim. Sci. 42:644-654.

Ettema, J. F., and J. E. Santos. 2004. Impact of age at calving on lactation, reproduction, health, and income in first-parity Holsteins on commercial farms. J. Dairy Sci. 87:2730-2742.

Fowler, P. A., C. H. Knight, and M. A. Foster. 1991. In vivo magnetic resonance imaging studies of mammogenesis in non-pregnant goats treated with exogenous steroids. J. Dairy Res. 58:151-157.

Fulkerson, W. J. 1978. Artificial induction of lactation: A comparative study in heifers. Aust. J. Biol. Sci. 31:65-71.

Guy, M. A., T. B. McFadden, D. C. Cockrell, and T. E. Besser. 1994. Effects of unilateral prepartum milking on concentrations of immunoglobulin $\mathrm{G}_{1}$ and prolactin in colostrum. J. Dairy Sci. 77:3584-3591.

Heald, C. W. 1974. Hormonal effects on mammary cytology. J. Dairy Sci. 57:917-925.

Kensinger, R. S., D. E. Bauman, and R. J. Collier. 1979. Season and treatment effects on serum prolactin and milk yield during induced lactation. J. Dairy Sci. 62:1880-1888.

Keys, J. E., A. V. Capuco, R. M. Akers, and J. Djiane. 1989. Comparative study of mammary gland development and differentiation between beef and dairy heifers. Domest. Anim. Endocrinol. 6:311-319.

Macrina, A. L., A. C. W. Kauf, and R. S. Kensinger. 2011a. Effect of bovine somatotropin administration during induction of lactation in 15-month-old heifers on production and health. J. Dairy Sci. 94:4566-4573

Macrina, A. L., R. S. Kensinger, and P. R. Tozer. 2011b. Induced lactation in pubertal heifers: Efficacy, response to bovine somatotropin, and profitability. J. Dairy Sci. 94:1355-1364.

Magliaro, A. L., R. S. Kensinger, S. A. Ford, M. L. O'Connor, L. D Muller, and R. Graboski. 2004. Induced lactation in nonpregnant cows: Profitability and response to bovine somatotropin. J. Dairy Sci. 87:3290-3297.

NRC. 1989. Nutrient Requirements of Dairy Cattle. 6th rev. ed. Natl Acad. Sci., Washington, DC.

NRC. 2001. Nutrient Requirements of Dairy Cattle. 7th rev. ed. Natl. Acad. Sci., Washington, DC.

Peel, C. J., J. W. Taylor, I. B. Robinson, A. A. McGowan, R. D Hooley, and J. K. Findlay. 1978. The importance of prolactin and the milking stimulus in the artificial induction of lactation in cows. Aust. J. Biol. Sci. 31:187-195.

Sinha, Y. N., and H. A. Tucker. 1969. Mammary development and pituitary prolactin level of heifers from birth through puberty and during the estrous cycle. J. Dairy Sci. 52:507-512. 
Smith, K. L., and F. L. Schanbacher. 1973. Hormone induced lactation in the bovine. I. Lactational performance following injections of 17ß-estradiol and progesterone. J. Dairy Sci. 56:738-743.

Smith, K. L., and F. L. Schanbacher. 1974. Hormone induced lactation in the bovine. II. Response of nulligravida heifers to modified estrogen-progesterone treatment. J. Dairy Sci. 57:296-303.

Tyrrell, H. F., and J. T. Reid. 1965. Prediction of the energy value of cow's milk. J. Dairy Sci. 48:1215-1223.
Van Amburgh, M. E., D. M. Galton, D. E. Bauman, R. W. Everett, D. G. Fox, L. E. Chase, and H. N. Erb. 1998. Effects of three prepubertal body growth rates on performance of Holstein heifers during first lactation. J. Dairy Sci. 81:527-538.

Winger, K., C. C. Gay, and T. E. Besser. 1995. Immunoglobulin $\mathrm{G}_{1}$ transfer into induced mammary secretions: The effect of dexamethasone. J. Dairy Sci. 78:1306-1309. 